\title{
Neuropathic pruritus following Wallenberg syndrome
}

\section{Figure Brain MRI and cutaneous lesions}
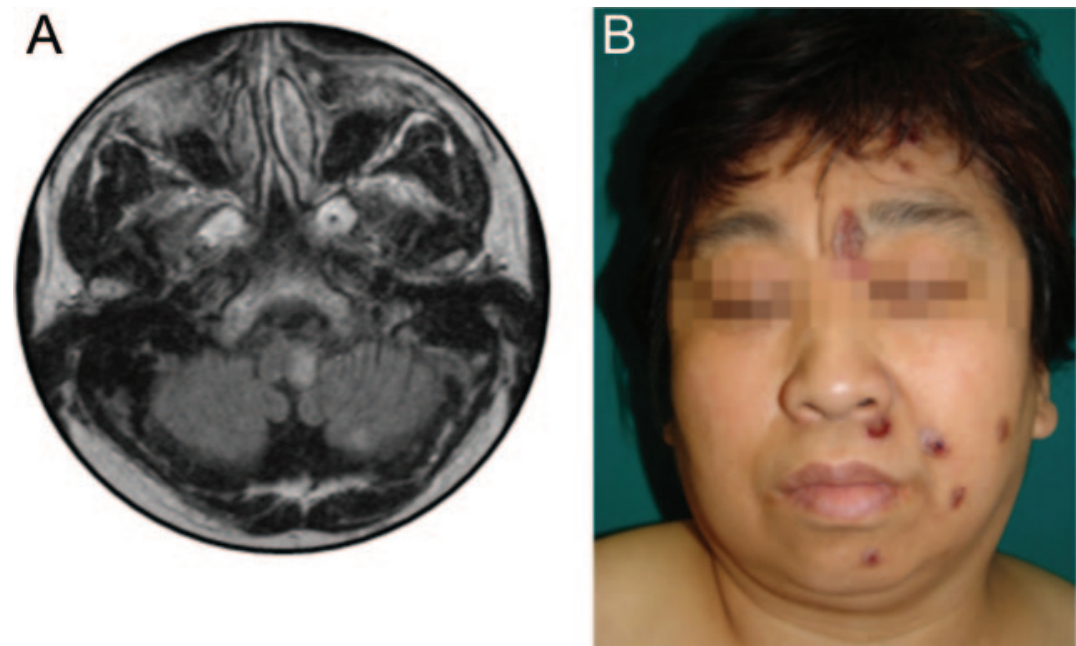

Axial brain MRI (fluid-attenuated inversion recovery) shows acute infarctions in the left medulla (A). The excoriated lesions developed on the left side of the face (B) due to poststroke pruritus.

Pruritus (itch) is not a well-known poststroke symptom. ${ }^{1}$ A 56 -year-old woman presented with Wallenberg syndrome. Three weeks after stroke, she developed excoriations of the paresthetic areas and contralateral trunk, which were secondary cutaneous lesions caused by scratching (figure). Three months later, the pruritus was resolved by gabapentin and topical therapy with moisturizers. The pathophysiology is not clear, but it has been suggested that the neural pathways and activated brain patterns responsible for pruritus and pain broadly overlap. ${ }^{2}$ This investigation led to the introduction of several centrally acting substances for treating neuropathic pruritus. Although rare, pruritus should be considered a poststroke symptom.

W.K. Seo, MD, D.Y. Kwon, MD, S.H. Seo, MD, PhD, M.H. Park, MD, PhD, K.W. Park, MD, PhD, AnsanCity, Gyeonggi-do, South Korea

Disclosure: The authors report no disclosures.

Address correspondence and reprint requests to Dr. Moon Ho Park, Department of Neurology, Korea University College of Medicine, 516, Gojan-1-dong, Danwon-gu, Ansan-City, Gyeonggi-do, 425-707, South Korea; parkmuno@yahoo.co.kr

1. Kimyai-Asadi A, Nousari HC, Kimyai-Asadi T, Milani F. Poststroke pruritus. Stroke 1999;30:692-693.

2. Ständer $S$, Weisshaar E, Luger TA. Neurophysiological and neurochemical basis of modern pruritus treatment. Exp Dermatol 2008;17:161-169. 


\title{
Neurology
}

\author{
Neuropathic pruritus following Wallenberg syndrome \\ W. K. Seo, D. Y. Kwon, S. H. Seo, et al. \\ Neurology 2009;72;676 \\ DOI 10.1212/01.wnl.0000342484.99298.52
}

This information is current as of February 16, 2009

\section{Updated Information \& Services}

References

Citations

Subspecialty Collections

Permissions \& Licensing

Reprints including high resolution figures, can be found at: http://n.neurology.org/content/72/7/676.full

This article cites 2 articles, 1 of which you can access for free at: http://n.neurology.org/content/72/7/676.full\#ref-list-1

This article has been cited by 1 HighWire-hosted articles: http://n.neurology.org/content/72/7/676.full\#\#otherarticles

This article, along with others on similar topics, appears in the following collection(s):

All Cerebrovascular disease/Stroke

http://n.neurology.org/cgi/collection/all_cerebrovascular_disease_strok e

Infarction

http://n.neurology.org/cgi/collection/infarction

Information about reproducing this article in parts (figures,tables) or in its entirety can be found online at:

http://www.neurology.org/about/about_the_journal\#permissions

Information about ordering reprints can be found online:

http://n.neurology.org/subscribers/advertise

Neurology ${ }^{\circledR}$ is the official journal of the American Academy of Neurology. Published continuously since 1951, it is now a weekly with 48 issues per year. Copyright . All rights reserved. Print ISSN: 0028-3878. Online ISSN: 1526-632X.

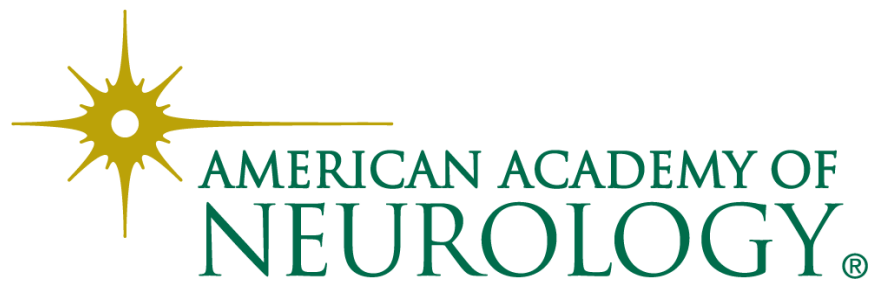

